\title{
Yersinia pekkanenii sp. nov.
}

\author{
Anna Murros-Kontiainen, ${ }^{1}$ Per Johansson, ${ }^{1}$ Taina Niskanen, ${ }^{1,2}$ \\ Maria Fredriksson-Ahomaa, ${ }^{1}$ Hannu Korkeala ${ }^{1}$ and Johanna Björkroth ${ }^{1}$ \\ ${ }^{1}$ Department of Food Hygiene and Environmental Health, Faculty of Veterinary Medicine, \\ University of Helsinki, Finland \\ ${ }^{2}$ Finnish Food Safety Authority Evira, Hygiene Unit, Helsinki, Finland
}

Correspondence

Johanna Björkroth

johanna.bjorkroth@helsinki.fi
This manuscript focuses on three strains: $\AA 125 \mathrm{KOH} 2$, $\AA \mathrm{YV} 25 \mathrm{~K} 1$ and $\AA \mathrm{YV} 7.1 \mathrm{KOH} 2^{\mathrm{T}}$, originating from water, soil and lettuce samples, respectively. API $20 \mathrm{E}$ (bioMérieux) and some other phenotypic tests suggested that the strains belong to Yersinia pseudotuberculosis. This was considered controversial because, among others, the study of Niskanen et al. (2009) showed that the strains lacked the virulenceencoding genes inv and virF. In addition, their NotI digests, 16S-23S rRNA gene HindIII and EcoRI RFLP (ribotype) patterns and the $\mathrm{O}$-antigen gene cluster were not typical for $Y$. pseudotuberculosis. In this study, multilocus sequence analysis of the 16S rRNA gene and four housekeeping genes, DNA G + C content determination and DNA-DNA hybridization tests clarified the taxonomic position of strains $\AA 125 \mathrm{KOH} 2$, $̊ Y V 25 \mathrm{~K} 1$ and $\AA Y Y 7.1 \mathrm{KOH} 2^{\mathrm{T}}$. Additional phenotypic tests and EcoRI and HindIII ribotyping were also done. The $g \ln A, \operatorname{gyr} B, \operatorname{rec} A$ and $H S P 60$ genes, which had previously been used in a multilocus sequence typing study for the genus Yersinia, were chosen for the housekeepinggene analysis because they provided the largest set of sequences for comparison. Two of these genes, $g \ln A$ and recA, were used by Merhej et al. (2008) while describing the species Yersinia massiliensis.

Morphological properties of the strains were determined by Gram staining and transmission electron microscopy.

The GenBank/EMBL/DDBJ accession numbers for the 16S rRNA, gln $A$, gyr $B$, recA and $H S P 60$ gene sequences of strains $\AA 125 \mathrm{KOH} 2$, AYV25K1 and $\AA Y Y V 7.1 \mathrm{KOH}^{\top}{ }^{\top}$ are GQ451988-GQ452002.

A supplementary table and four supplementary figures are available with the online version of this paper.
Oxidase activity was tested with oxidase strips and catalase activity with $3 \%$ hydrogen peroxide. Biochemical characterization was done using the API $20 \mathrm{E}$ and API $50 \mathrm{CH}$ strips according to the instructions of the manufacturer (bioMérieux). The incubation temperature used was $28{ }^{\circ} \mathrm{C}$ and the results were read after 24, 48 and $72 \mathrm{~h}$. Each test was done at least twice. The motility test was performed at 28 and $37{ }^{\circ} \mathrm{C}$ using Motility Test and Maintenance and Motility Test media (Atlas \& Snyder, 2006).

DNA from strains $̊ 125 \mathrm{KOH} 2$, ̊̊Y 25K1, ̊̊YV7.1KOH2 ${ }^{\mathrm{T}}$, Yersinia aldovae CIP $103162^{\mathrm{T}}$ and Yersinia mollaretii DSM $18520^{\mathrm{T}}$ was extracted by the guanidium thiocyanate method described by Pitcher et al. (1989) with the addition of $0.6 \mathrm{mg}$ proteinase $\mathrm{K} \mathrm{ml}^{-1}$ to the cell suspension buffer. The $g \ln A, g y r B$, recA and $H S P 60$ genes were amplified using primers and amplification conditions described by Kotetishvili et al. (2005) with the exception of $g y r B$ (the annealing temperature was raised to $62{ }^{\circ} \mathrm{C}$ ). The $16 \mathrm{~S}$ rRNA gene was amplified with universal primers F19-38 and R1541-1522 (Stackebrandt \& Liesack, 1993). The PCR cycle for the 16S rRNA gene comprised denaturation at $98{ }^{\circ} \mathrm{C}$ for $2 \mathrm{~min}$, followed by 30 amplification cycles $\left(93{ }^{\circ} \mathrm{C}\right.$ for $1 \mathrm{~min}, 54{ }^{\circ} \mathrm{C}$ for $2 \mathrm{~min}$ and $72{ }^{\circ} \mathrm{C}$ for $2.5 \mathrm{~min}$ ) and final elongation at $72{ }^{\circ} \mathrm{C}$ for $8 \mathrm{~min}$. Each PCR mixture consisted of $200 \mu \mathrm{M}$ dNTPs, 0.02 IU DyNAZyme II polymerase $\mu \mathrm{l}^{-1}$ (Thermo Fisher Scientific Inc.) and $0.5 \mu \mathrm{M}$ each primer. PCR products were purified by the Millipore MultiScreen PCR 96 system. Bidirectional sequencing of the PCR products was done with the same primers as were used for amplification, using an Applied Biosystems BigDye Terminator v3.1 Cycle Sequencing kit 
and an ABI 3130XL Genetic Analyzer. Sequences were aligned and consensus sequences were created using BioNumerics 5.10 software (Applied Maths). 16S rRNA, $g \ln A, \operatorname{grr} B$, recA and HSP60 gene sequences of strains $\AA 125 \mathrm{KOH} 2$, $̊ Y V 25 \mathrm{~K} 1$ and $\AA Y Y 7.1 \mathrm{KOH}_{2}{ }^{\mathrm{T}}$ were deposited in GenBank with accession numbers GQ451988GQ452002. Supplementary Table S1 (available in IJSEM Online) presents the GenBank accession numbers of $g \ln A$, gyrB, HSP60 and recA gene sequences for type and reference strains used in this study. Maximum-parsimony and neighbour-joining trees with the Jukes-Cantor correction and bootstrap analysis (1000 replicates) were constructed using BioNumerics 5.10 software. Phylogenetic trees were constructed using the $16 \mathrm{~S}$ rRNA gene (1424 bp) and housekeeping genes $g \ln A$ (494 bp), gyrB (471 bp), recA (483 bp) and HSP60 (486 bp). Concatenated trees were constructed by combining $g \ln A$, gyrB, recA and HSP60 gene sequences. Serratia proteamaculans was used as an outgroup.

Ribotyping procedures and numerical analyses of the patterns were done according to Niskanen et al. (2009). Supplementary Fig. S1 (available in IJSEM Online) presents HindIII and EcoRI ribopatterns of strains $\AA 125 \mathrm{KOH} 2$,
$\AA$ IV25K1 and $\AA \mathrm{YV} 7.1 \mathrm{KOH} 2^{\mathrm{T}}$ and comparison with those of type strains of Yersinia species.

The DNA G + C content was determined as described by $\mathrm{Xu}$ et al. (2000). Melting-point curves were determined with a LightCycler instrument (Roche) using SYBR Green I dye (Roche); $1 \times$ SSC was used to obtain sharp melting curves. Y. aldovae CIP $103162^{\mathrm{T}}$ was used as the reference organism and Y. mollaretii DSM $18520^{\mathrm{T}}$ was used as the control.

DNA-DNA hybridization tests were done with strains ÅYV7.1KOH2 $2^{\mathrm{T}}$, ÅV25K1, Y. aldovae CIP $103162^{\mathrm{T}}$ and $Y$. mollaretii DSM $18520^{\mathrm{T}}$ according to Jakava-Viljanen et al. (2008). Each measurement was repeated three times.

Strains $̊ 125 \mathrm{KOH} 2$, ̊YV25K1 and $̊ Y Y V 7.1 \mathrm{KOH}_{2}{ }^{\mathrm{T}}$ were Gram-negative rods. The length of the cells was $1-3 \mu \mathrm{m}$ (Supplementary Fig. S2) after $24 \mathrm{~h}$ incubation on blood agar at $30^{\circ} \mathrm{C}$. Colonies were circular, convex and of pinpoint size after $24 \mathrm{~h}$ on blood agar at $30{ }^{\circ} \mathrm{C}$. Cells were non-motile at 28 and $37{ }^{\circ} \mathrm{C}$ in motility tests and under microscopic observation, oxidase-negative and catalasepositive. Biochemical characteristics of the strains are presented in Table 1 and are compared with those of other

Table 1. Biochemical characteristics of Yersinia pekkanenii sp. nov. compared with those of type strains of other Yersinia species

Type strains: 1, Y. pekkanenii sp. nov.; 2, Y. pseudotuberculosis; 3, Y. aldovae; 4, Y. mollaretii; 5, Y. bercovieri; 6, Y. intermedia; 7, Y. rohdei; 8, Y. enterocolitica subsp. enterocolitica; 9, Y. enterocolitica subsp. palearctica; 10, Y. aleksiciae; 11, Y. frederiksenii; 12, Y. kristensenii; 13, Y. pestis (Sprague et al., 2008); 14, Y. ruckeri; 15, Y. similis; 16, Y. massiliensis. All data are from this study unless otherwise indicated. Results are presented after 48 h incubation: +, positive; -, negative; $(+)$, weakly positive. All strains were positive for utilization of trehalose and glucose and negative for utilization of adonitol.

\begin{tabular}{|c|c|c|c|c|c|c|c|c|c|c|c|c|c|c|c|c|}
\hline Characteristic & 1 & 2 & 3 & 4 & 5 & 6 & 7 & 8 & 9 & 10 & 11 & 12 & 13 & 14 & 15 & 16 \\
\hline \multicolumn{17}{|l|}{ Utilization of: } \\
\hline D-Xylose & + & + & + & + & + & + & + & + & - & + & + & + & - & - & + & + \\
\hline Sorbose & - & - & - & + & - & + & - & + & + & - & + & + & - & - & - & + \\
\hline Aesculin & - & + & - & $(+)$ & - & + & - & - & - & - & + & - & + & - & + & + \\
\hline Salicin & - & + & - & $(+)$ & $(+)$ & + & $(+)$ & - & - & $(+)$ & + & + & - & - & $(+)$ & + \\
\hline Cellobiose & + & - & - & + & + & + & + & + & + & + & + & + & - & - & - & + \\
\hline Lactose & $(+)$ & - & - & $(+)$ & - & - & $(+)$ & - & - & - & - & + & - & - & - & - \\
\hline Raffinose & - & - & - & - & - & + & + & - & - & - & - & - & - & - & - & - \\
\hline Glycerol & - & $(+)$ & + & + & $(+)$ & + & + & + & + & + & + & + & - & + & + & + \\
\hline Citrate & - & - & + & + & - & + & + & - & - & - & + & - & - & - & + & + \\
\hline Inositol & - & - & + & $(+)$ & - & + & - & $(+)$ & + & $(+)$ & + & $(+)$ & - & - & - & + \\
\hline Sorbitol & - & - & + & + & + & + & + & + & + & + & + & + & - & - & - & + \\
\hline Melibiose & - & + & - & - & - & + & + & - & - & - & - & - & - & - & - & - \\
\hline Rhamnose & - & $(+)$ & + & - & - & + & - & - & - & - & + & - & - & - & + & - \\
\hline ONPG & + & + & - & + & + & + & + & + & + & + & + & + & - & + & + & + \\
\hline Sucrose & - & - & - & + & + & + & + & + & + & - & + & - & - & - & - & $(+)$ \\
\hline L-Arabinose & + & - & + & + & + & + & + & + & + & + & + & + & + & - & + & + \\
\hline Urea hydrolysis & + & + & + & + & + & + & + & + & + & + & + & + & - & - & + & + \\
\hline Lysine decarboxylase & - & - & - & - & - & - & - & - & - & - & - & - & - & + & - & - \\
\hline Ornithine decarboxylase & - & - & + & + & + & + & + & + & + & + & + & + & - & + & - & + \\
\hline $\begin{array}{l}\text { Voges-Proskauer } \\
\text { reaction }\end{array}$ & - & - & + & - & - & + & - & - & - & - & + & - & - & - & - & - \\
\hline Indole production & - & - & - & - & - & + & - & + & - & - & + & + & - & - & - & + \\
\hline
\end{tabular}


Yersinia species. The API 20 E (bioMérieux) profile obtained for strains $\AA 125 \mathrm{KOH} 2, \AA$, 25251 and ÅYV7.1KOH2 $2^{\mathrm{T}}$ was $1014103(98.4 \%$ identity with $Y$. pseudotuberculosis). As reported previously (Niskanen et al., 2009), these strains cannot be differentiated from Y. pseudotuberculosis by using API $20 \mathrm{E}$ or other phenotypic tests.

The three strains had identical $g \ln A$ (492 bp), $\operatorname{gyr} B$ (502 bp), recA (512 bp), HSP60 (523 bp) and 16S rRNA (1451 bp) gene sequences. In phylogenetic analyses of the housekeeping-gene sequences $g \ln A, g y r B$, recA and HSP60, they formed a unique group (Fig. 1; Supplementary Fig. S3, available in IJSEM Online) within the genus Yersinia. Depending on the analysis, either $Y$. mollaretii (Supplementary Fig. S3) or $Y$. aldovae (Fig. 1) was located as the closest phylogenetic neighbour, with low $(<40 \%)$ bootstrap support. Phylogenetic analysis of the $16 \mathrm{~S}$ rRNA gene sequences also grouped the strains together with $Y$. aldovae and $Y$. mollaretii (Fig. 2; Supplementary Fig. S4, available in IJSEM Online) with higher bootstrap support ( $>60 \%)$, but the DNA-DNA hybridization results showed that the three strains belonged to neither $Y$. aldovae nor $Y$. mollaretii. Strains AYY7.1 $\mathrm{KOH} 2^{\mathrm{T}}$ and $\AA \mathrm{YV} 25 \mathrm{~K} 1$ had hybridization values of $32-47$ and $29-39 \%$ with Y. aldovae CIP $103162^{\mathrm{T}}$ and Y. mollaretii DSM $18520^{\mathrm{T}}$, respectively. Strains $\AA 125 \mathrm{KOH} 2$, $̊ Y V 25 \mathrm{~K} 1$ and $\AA Y Y 7.1 \mathrm{KOH} 2^{\mathrm{T}}$ had $16 \mathrm{~S}$ rRNA gene sequence similarity of $99.9 \%$ to Y. aldovae CIP $103162^{\mathrm{T}}$. With the type strains of other Yersinia species, the 16 rRNA gene sequence similarity was $98.0-99.3 \%$.

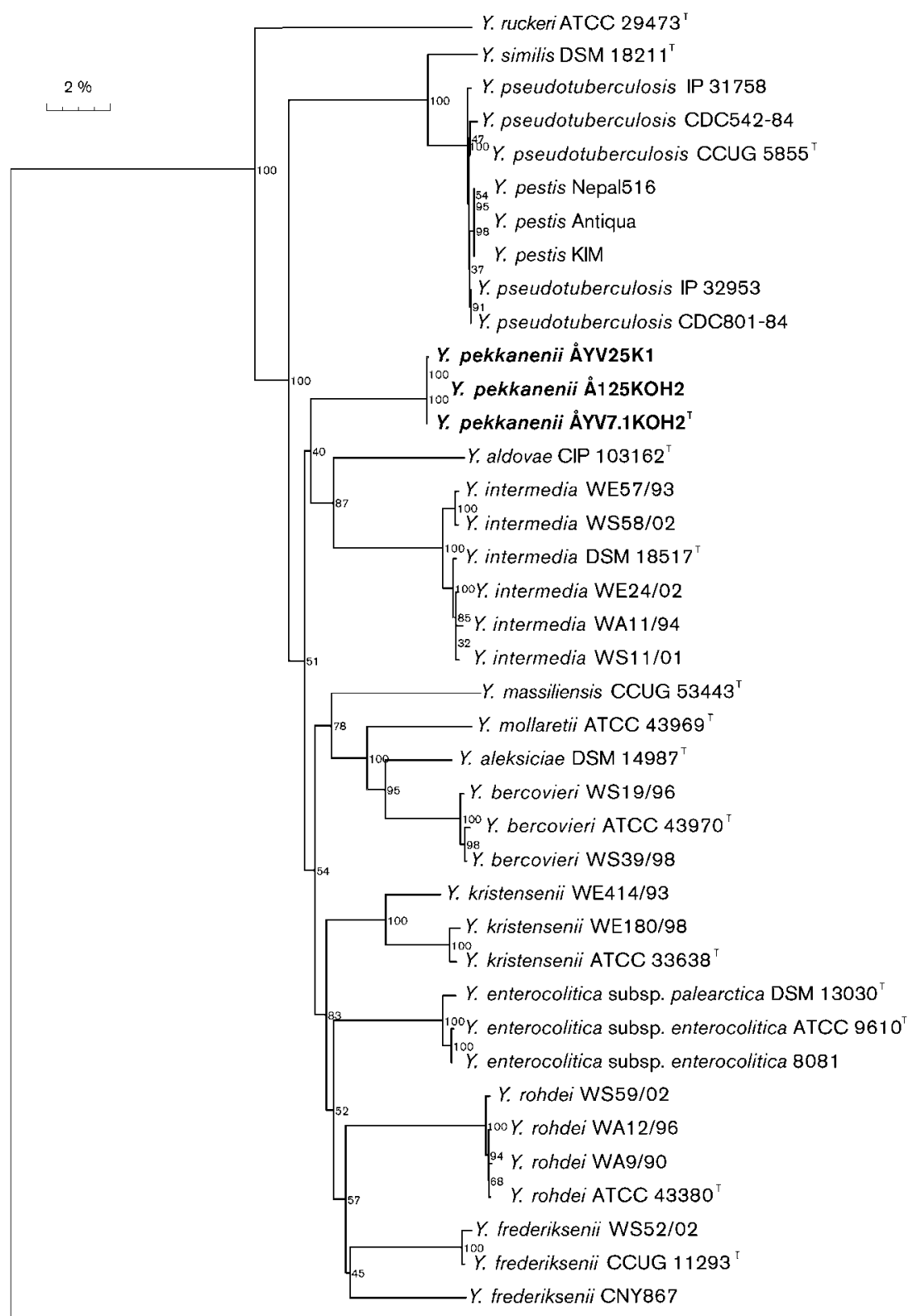

S. proteamaculans 568
Fig. 1. Neighbour-joining tree based on concatenated $g \ln A, \operatorname{gyr} B, H S P 60$ and $\operatorname{rec} A$ gene sequences of Yersinia pekkanenii sp. nov. and type and reference strains of the genus Yersinia. Bootstrap values (\%) for 1000 replicates are given at branch points. $S$. proteamaculans was used as outgroup. Bar, $2 \%$ difference in nucleotide sequence. 


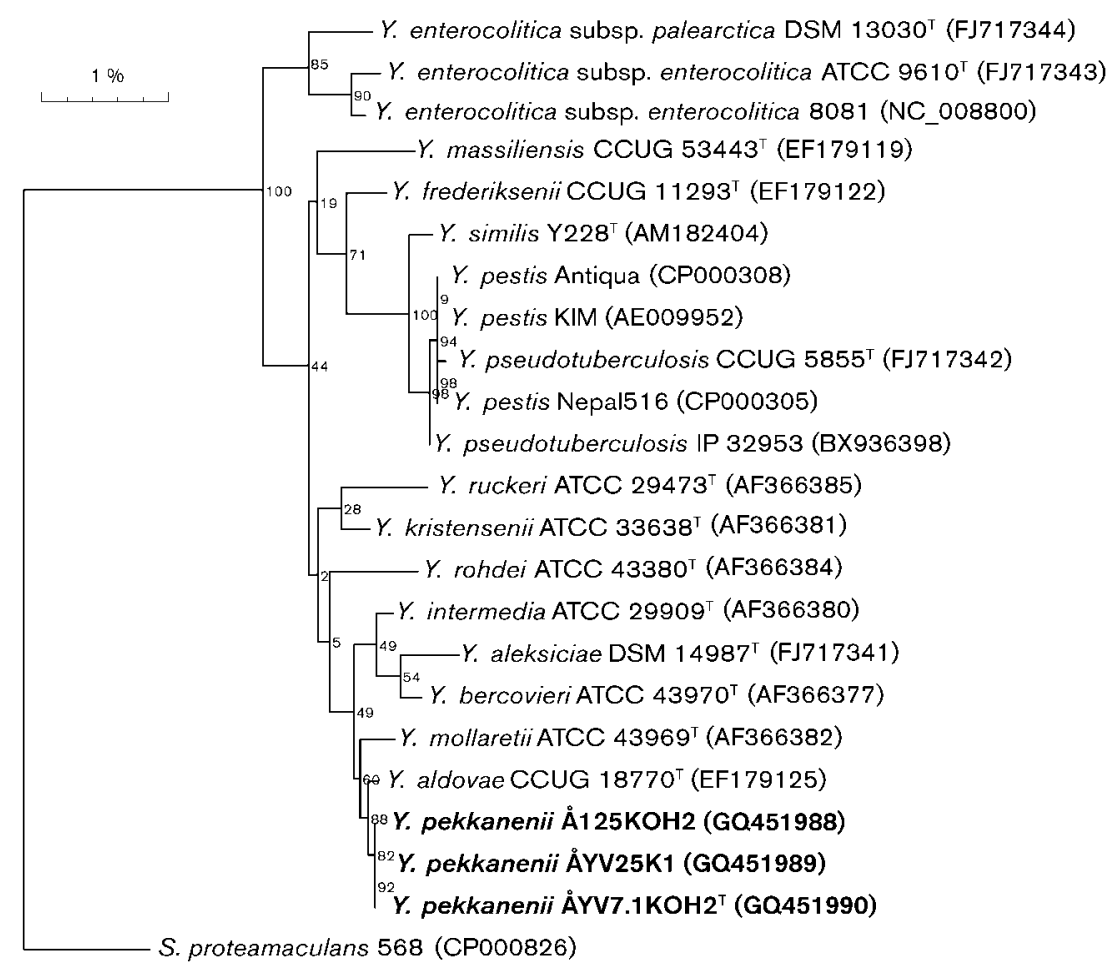

Fig. 2. Neighbour-joining tree based on $16 \mathrm{~S}$ rRNA gene sequences of Yersinia pekkanenii sp. nov. and type and reference strains of the genus Yersinia. Bootstrap values (\%) for 1000 replicates are given at branch points. $S$. proteamaculans was used as outgroup. GenBank accession numbers are shown in parentheses. Bar, $1 \%$ difference in nucleotide sequence.
Numerical analyses of both HindIII and EcoRI ribopatterns supported the results of the housekeeping-gene analysis. Strains $̊ 125 \mathrm{KOH} 2$, ÅV25K1 and ÅY 7.1KOH2 ${ }^{\mathrm{T}}$ formed a separate cluster within the genus Yersinia (Fig. 1). The DNA G + C contents of strains $\AA 125 \mathrm{KOH} 2, \AA$ AYV25K1 and AYV7.1KOH $2^{\mathrm{T}}$ were identical at $47.5 \mathrm{~mol} \%$.

It is proposed that strains $\AA 125 \mathrm{KOH} 2$, $\mathrm{YYV} 25 \mathrm{~K} 1$ and AYV7.1KOH $2^{\mathrm{T}}$ represent a novel species in the genus Yersinia, for which the name Yersinia pekkanenii sp. nov. is suggested.

\section{Description of Yersinia pekkanenii sp. nov.}

Yersinia pekkanenii (pek.ka.ne'ni.i. N.L. gen. masc. n. pekkanenii in honour of the late Professor Timo Pekkanen, who was a veterinarian and former head of the Department of Food and Environmental Hygiene in the Faculty of Veterinary Medicine of the University of Helsinki. He made a substantial contribution to the development of scientific research of food hygiene in Finland).

Cells are Gram-negative rods of $1-3 \mu \mathrm{m}$ diameter and are non-motile, oxidase-negative and catalase-positive. Positive for urea hydrolysis and ONPG utilization. Ferments D-xylose, cellobiose, trehalose, L-arabinose and glucose. Ferments lactose weakly. Does not ferment adonitol, sorbose, salicin, raffinose, glycerol, inositol, sorbitol, melibiose, rhamnose or sucrose. Negative for lysine decarboxylase, ornithine decarboxylase, VogesProskauer reaction, lipase and indole production. Does not hydrolyse aesculin. Grows on blood, tryptic soy, MacConkey and nutrient agar at $25-37^{\circ} \mathrm{C}$. Produces pinpoint colonies on blood agar at $30{ }^{\circ} \mathrm{C}$ in $24 \mathrm{~h}$. Colonies are circular and convex. DNA $\mathrm{G}+\mathrm{C}$ content is $47.5 \mathrm{~mol} \%$. 16S rRNA gene sequence similarity with $Y$. aldovae CIP $103162^{\mathrm{T}}$ is $99.9 \%$.

The type strain is $\AA Y$ YV7.1KOH2 ${ }^{\mathrm{T}}$ (=DSM $22769^{\mathrm{T}}=\mathrm{LMG}$ $25369^{\mathrm{T}}$ ), isolated from a lettuce sample. Reference strains are $\AA 125 \mathrm{KOH} 2$ and $\AA \mathrm{YV} 25 \mathrm{~K} 1$, isolated from water and soil samples, respectively, suggesting an environmental habitat.

\section{Acknowledgements}

We are grateful to the Academy of Finland for supporting our research financially through the ELVIRA programme (decision no. 1117921) and through funding to the Finnish Centre of Excellence in Microbial Food Safety Research (decision no. 1118602). DVM Riitta Rahkila is acknowledged for her help during revision of the manuscript and we thank E. Merivirta for her technical assistance.

\section{References}

Atlas, R. M. \& Snyder, J. W. (2006). Handbook of Media for Clinical Microbiology, 2nd edn. Boca Raton, FL: CRC Press.

Jakava-Viljanen, M., Murros, A., Palva, A. \& Björkroth, K. J. (2008). Lactobacillus sobrius Konstantinov et al. 2006 is a later synonym of Lactobacillus amylovorus Nakamura 1981. Int J Syst Evol Microbiol 58, 910-913.

Kotetishvili, M., Kreger, A., Wauters, G., Morris, J. G., Jr, Sulakvelidze, A. \& Stine, O. C. (2005). Multilocus sequence typing for studying genetic relationships among Yersinia species. J Clin Microbiol 43, 2674-2684. 
Merhej, V., Adékambi, T., Pagnier, I., Raoult, D. \& Drancourt, M. (2008). Yersinia massiliensis sp. nov., isolated from fresh water. Int $J$ Syst Evol Microbiol 58, 779-784.

Niskanen, T., Laukkanen, R., Murros, A., Björkroth, J., Skurnik, M., Korkeala, H. \& Fredriksson-Ahomaa, M. (2009). Characterisation of non-pathogenic Yersinia pseudotuberculosis-like strains isolated from food and environmental samples. Int J Food Microbiol 129, 150-156.

Pitcher, D. G., Saunders, N. A. \& Owen, R. J. (1989). Rapid extraction of bacterial genomic DNA with guanidium thiocyanate. Lett Appl Microbiol 8, 151-156.
Sprague, L. D., Scholz, H. C., Amann, S., Busse, H.-J. \& Neubauer, H. (2008). Yersinia similis sp. nov. Int J Syst Evol Microbiol 58, 952-958. Stackebrandt, E. \& Liesack, W. (1993). Nucleic acids and classification. In Handbook of New Bacterial Systematics, pp. 152-194. Edited by M. Goodfellow \& A. G. O'Donnell. London, UK: Academic Press.

Xu, H. X., Kawamura, Y., Li, N., Zhao, L., Li, T. M., Li, Z. Y., Shu, S. \& Ezaki, T. (2000). A rapid method for determining the $\mathrm{G}+\mathrm{C}$ content of bacterial chromosomes by monitoring fluorescence intensity during DNA denaturation in a capillary tube. Int $J$ Syst Evol Microbiol 50, 1463-1469. 